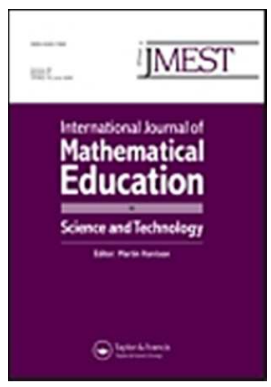

\title{
Emotional and cognitive effects of peer tutoring among secondary school mathematics students
}

\begin{tabular}{|r|l|}
\hline Journal: & $\begin{array}{l}\text { International Journal of Mathematical } \\
\text { Education in Science and Technology }\end{array}$ \\
\hline Manuscript ID & TMES-2016-0001.R3 \\
\hline Manuscript Type: & Paper \\
\hline Keywords: & $\begin{array}{l}\text { peer tutoring, solidarity, mathematics self- } \\
\text { concept }\end{array}$ \\
\hline $\begin{array}{r}<\mathrm{a} \\
\text { href="http://www.ams.org/mathscinet/msc/msc2010.html" } \\
\text { target="_blank" }>2010 \text { Mathematics Subject } \\
\text { Classification</a>: }\end{array}$ & $\begin{array}{l}97-02 \text { Research exposition (monographs, } \\
\text { survey articles) }\end{array}$ \\
\hline \multicolumn{2}{|c|}{} \\
\hline
\end{tabular}

SCHOLARONE ${ }^{\text {m }}$

Manuscripts

URL: http://mc.manuscriptcentral.com/tmes Email: ijmest@lboro.ac.uk 
Emotional and cognitive effects of peer tutoring among secondary school mathematics students

\begin{abstract}
This paper describes an experience of same-age peer tutoring conducted with 19 eighthgrade mathematics students in a secondary school in Castellon de la Plana (Spain). Three constructs were analysed before and after launching the program: academic performance, mathematics self-concept, and attitude of solidarity. Students' perceptions of the method were also analysed. The quantitative data was gathered by means of a mathematics self-concept questionnaire [45], an attitude of solidarity questionnaire [46] and the students' numerical ratings. A statistical analysis was performed using Student's t-test. The qualitative information was gathered by means of discussion groups and a field diary. This information was analysed using descriptive analysis and by categorizing the information. Results show statistically significant improvements in all the variables and the positive assessment of the experience and the interactions that took place between the students.
\end{abstract}

Keywords: peer tutoring, solidarity, mathematics self-concept. 


\section{Introduction}

Student heterogeneity is a reality, mirroring the heterogeneity of our society, and it must be seen as a chance to "maximize" the teaching/learning processes. Diversity should be turned into a challenge, an opportunity to learn with and from human differences. The fact that every single person is different must be recognized, therefore allowing each child to receive the best educational response possible at school [1]. Over the last decade, the theoretical framework of inclusive education has been used to enhance the positive evaluation of diversity. This movement is considered to be a system of values and beliefs that is a crucial element in the improvement process [2]. In our context, cooperative learning is still not sufficiently rooted in our education system and remains underrated, which contradicts the intense demands of today's society for social and teamwork skills [3]. If the socialization processes in the family and in society are important for academic performance, then socialization in the classroom, which takes place through the social interaction among classmates, might be even more important. Ashman and Gillies [4,p.20] claim that cooperative learning activities "provide an ideal vehicle for teachers to structure the environment for successful peer interactions and [...] provide students with the coaching and support they need to develop their social and emotional skills and understanding”. Dialogue, discussion and mutual explanations encourage cognitive thinking and develop understanding; but furthermore, confrontation between different points of view also helps to restructure knowledge schemes through the appearance of socio-cognitive conflict [5].These issues materialize in a learning method known as peer tutoring, the subject of this article. 


\section{Peer Tutoring: learning to teach and teaching to learn}

As mentioned above, the interaction between students and their classmates has a significant impact on the learning process. By interacting with others, students generate a series of cognitive conflicts that make them learn [6]. Authors such as Duran [7] state that sometimes students can be better mediators than adults. They argue that because students have just recently learned the contents, they are more sensitive to the areas in which their classmates might require more help. In addition, they use more direct language and have the added advantage of sharing cultural and linguistic references. Topping [8,p.2] defines peer tutoring as "people from similar social groupings who are not professional teachers helping each other to learn and learning themselves by teaching”.

Different types of peer tutoring essentially depend on two factors: the ages of the pairs and the continuity of the role.

The first type includes cross-age tutoring and same-age tutoring. Cross-age tutoring is the most prevalent in the North American context. Linton [9] claimed that tutees make greater progress with tutors four years older than themselves. According to Lippit [10], the difference in age guarantees the quality of the process, and considers the ideal difference to be between 2 and 4 years. Allen and Feldman [11] concluded that students preferred this format. Nevertheless, recent studies show that the most effective tutoring occurs between students of the same age, the second type (same-age tutoring). Burnish [12] and Topping [13] showed that peer tutoring between people of the same age was at least as effective, or more so, than tutoring between people of different ages. Same-age tutoring has the added advantage of the proximity between students, and because it takes place in the same class group it does not require any previous organizational actions [14]. A meta-analysis carried 
out by Leung [15] examined the effectiveness of cross-age and same-age peer tutoring. Results showed they were both equally effective.

Same-age tutoring may involve two types of tutoring, fixed or reciprocal, depending on the role of the students. In fixed peer tutoring the tutor student and the tutee student always have the same role: one of them explains and the other asks questions. In contrast, in reciprocal tutoring the roles are exchanged. The research reported in this paper concerns fixed peer tutoring.

\section{State of the art: the potential of peer tutoring}

Nearly all the meta-analyses in the literature reflect the great potential of peer tutoring and its positive impact on students' academic performance and affective construct. Ritter et al. [16] evaluated the efficacy of 21 voluntary peer tutoring programs and found that these interactions had a positive effect on the students' academic achievement. Apart from the purely academic variables, peer tutoring also had a positive impact on the emotional variables. Spencer [17] carried out a review of 38 studies concluding that peer tutoring had a positive impact on the emotional and behavioural disorders of the students whether they are tutors or tutees. Byrd [18] analysed 18 empirical studies. She concluded that, among other benefits, peer tutoring reported benefits on students' integration, self-esteem, performance or classroom atmosphere.

In secondary education studies the benefits students acquire when they participate in peer tutoring programs has also been documented. Duran and Flores [19] checked how students' reading self-concept improved because of peer tutoring. Gavota et al. [20] investigated how their students improved their writing skills by reviewing and correcting 
their peers. Scheeler et al. [21] concluded that the immediate feedback given by the tutors improved the oral expression of their peers. Spörer and Brunstein [22] showed the benefits in the reading comprehension skills of the students by using peer tutoring. Duran and Monereo [23] research documented an increase in the students' self-concept using both, fixed and reciprocal peer tutoring. In other subjects such as physics, Ismail and Alexander [24] presented better results with structured peer tutoring programs. In mathematics, the studies of Gautreaux [25] and Nazzal [26] showed how peer tutoring helped students improve their academic performance.

All these benefits correspond to the aspects that most teachers aspire to achieve in their classrooms: advantages referring to instructional, social and affective aspects. The research essentially highlights the academic value of learning between peers in different fields of study.

Three constructs that form part of this study emerged from the literature review. We now look at some of their key aspects.

\section{Academic performance}

To test the efficiency of a learning-teaching method, the impact it has on performance or the acquisition and consolidation of the contents and/or abilities needs to be demonstrated. Academic performance refers to the assessment of knowledge acquired in the school environment; it is a measure of students' abilities that express what they have learned throughout a training process. Knowles [27, p.273] defines academic performance as "the demonstrated achievement of learning as opposed to the potential for learning”, understanding achievement as "knowledge attained or skills developed in school subjects usually designed by test scores or marks assigned by the teacher or both." 
The secondary education students' performance in mathematics has been the subject of numerous studies. Martin and Debus [28] concluded that both motivation and mathematics self-concept played a determining role in students' mathematics performance, reinforcing the idea posited by Pajares [29] according to which those students who see themselves as more competent in a subject or field of study are more likely to engage in tasks related to these learning domains, and obtain better grades in the subject. For their part, Miñano and Castejón [30], in a study with 341 seventh grade students, pointed out that self-concept varied depending on the experiences of the students in the classroom. Students' motivational profiles and school success are not so much modulated by their individual aptitudes, but more by their experiences of success and/or failure in the corresponding areas, stressing the reciprocal relation between motivation and learning/execution. In other words, motivation influences the learning and execution processes, and what the students learn and do affects their motivation; this idea had previously been expounded by authors such as Pintrich, Marx and Boyle. [31]

\section{Mathematics self-concept}

Although many authors have studied self-concept, there is no unanimous definition of what it is. According to Hattie [32,p.37], self-concept is "the cognitive appraisal one makes of the expectations, descriptions, and prescriptions that one holds about one's self." Shavelson and Bolus [33,p.1] define self-concept as "a person's perception of him or herself. [...] Those perceptions are formed through one's experience with and interpretations of one's environment and are influenced especially by evaluations of significant others, reinforcements, and one's attributions for one's own behaviour." 
As the present study focuses on the field of mathematics, we now address the concept of mathematics self-concept. According to Gómez-Chacón [34], a student's mathematics selfconcept is one of the constructs that will ultimately have the greatest influence on his or her own learning. Many authors consider that mathematics self-concept plays a key role in mathematics teaching and is related to the student's attitudes, mathematics world perspective and social identity. [35, 36] Some key elements of mathematics self-concept are: interest in mathematics, efficiency in mathematics, motivation and taking pleasure in mathematics, and attributing success or failure in mathematics to chance. According to Gomez-Chacón [34], mathematics self-concept refers to people's self-image in terms of the way they perceive and value themselves when learning mathematics. She considers it to be linked to the beliefs that each individual holds about the world of mathematics, beliefs that are shaped throughout the students' schooling.

\section{Attitude of solidarity}

For each compulsory school subject, the Spanish education system stipulates a series of principles that should be encouraged in classroom. One of them is the principle of solidarity which is referred to on seven occasions in the LOE (Organic Law of Education). This principle is therefore an integral part of the objectives and aims of the current education system. According to Hondrich and Koch-Arzberger [37, p.14], solidarity may be defined as "a sense of community between persons who, despite their differences, believe to have the same objective(s) that one has achieved more than the other, from which rises the voluntary obligation to support the other, coupled with the entitlement to support from the other should the situation be reversed." Aside from what is provided by law, most authors agree that students must receive instruction not only from an academic perspective, but also 
from a moral one. According to Cortina [38] moral education and the forming of attitudes are basic tasks that are even more important than the transfer of contents. Prosocial conducts refer to actions designed to benefit others in some way. Attitude is the direction of the conduct, an evaluative affirmation or judgment in relation to objects, people or facts. $[39,40]$. Prosociality is understood as those behaviours that benefit other people, groups or social goals, as well as increasing the probability of generating a positive, high quality reciprocity based on solidarity in interpersonal or social relations, protecting the identity, creativity and initiative of the people or groups involved. [41] By recognizing otherness, a true "we" without borders is created; this universality is the prime place for the action of teaching. The dynamic relation between the recognition of the individual and the opening up to the world is the specific space of solidarity. [42]

Peer tutoring is a cooperative learning strategy with potential advantages that can greatly benefit students. The aim of this research is therefore to analyse the effects of fixed peer tutoring in emotional (self-concept), attitudinal (solidarity) and academic (performance) constructs of mathematics students. We also aim to discover their level of satisfaction and the interactions and help that take place in the peer tutoring program through their perceptions and participant observation.

\section{Hypotheses}

- Students' mathematics self-concept will increase significantly with the implementation of the peer tutoring program. 
- Students' academic performance will improve significantly with the implementation of the peer tutoring program.

- Students' attitude of solidarity will increase significantly with the implementation of the peer tutoring program.

- The students will be satisfied with the implementation of the peer tutoring program and with the interactions and help established.

\section{Method}

\section{The peer tutoring program}

The components of the peer tutoring program implemented are described below. This experience is based on the Llegim en Parella (Reading in pairs) project (GRAI research group).

-Grade level, subject area, objectives, strands and competences.

\section{Grade level: Eighth Grade}

Subject area: Mathematics

Objectives: Below we list some of the objectives stipulated in the DOGV (Decree $112 / 2007$, of 20 July) concerning the subject of mathematics that the students worked with on this program: To address concepts from situations that students find intuitive. These concepts are then returned to at a later date and addressed from different perspectives that add new, more complex elements; to develop students' capacity to verbally express the processes they followed to solve the problems; to increase the students' confidence in their 
own capacities to interpret, value and take decisions on situations that have a mathematical basis, highlighting the importance of affective teaching factors and learning mathematics; to improve capacity for reflective thinking and incorporating ideas; to deal with the problems of daily life following the intrinsic modes of mathematical activity by exploring alternatives systematically, using precise language, being flexible and adaptable to changes in points of view, and persevering in seeking solutions; to develop a positive attitude toward problem-solving, show confidence in one's own capacity and succeed in solving the problem, and acquire an appropriate level of self-esteem that allows the student to enjoy the creative, manipulative, artistic and useful aspects of mathematics; and to value mathematics and consider them as an integral part of our culture, both from a historical point of view and from the perspective of the current role they play in today's society.

Contents: The contents correspond to the second and third term of the eighth-grade mathematics course. Other contents common to all the subjects stipulated in the decree were also studied using the peer tutoring program: figures that have the same shape and different dimensions. Geometrical proportions. Proportional segments. Identification of geometrical relationships; Pythagoras' theorem and Thales' theorem. Solving problems and checking relationships between figures; Polyhedrons and solids of revolution. Flat surface development and characteristic elements. Classifications considering different criteria. Using properties, regularities and relationships to solve physical world problems; Volumes of geometric objects. Solving problems involving estimations and calculation of lengths, surfaces and volumes.

-Scheduling 
The program was scheduled to run over 15 sessions, all held during the third term of the course. In the first session the students completed questionnaires on their mathematics self-concept and attitude of solidarity. The second session was devoted to training students in the peer tutoring program. Ten peer tutoring sessions were then held on separate days. The length of each session varied according to the difficulty and complexity of the problems and the students were given more or less time to solve them accordingly. At the end of these sessions, the students took the final third term exam on the material studied over the period. The program concluded with the students once again completing the questionnaires on the mathematics self-concept and attitude of solidarity, and then they formed discussion groups to appraise the experience.

-Selecting the peers

Peers were selected as follows: the list of students was split in two according to their marks from previous assessments; the first half was the group of tutors and the second, the tutees. Pairs were formed in such a way that the most proficient tutor was paired with the most proficient tutee and so on until the list was completed.

-Training

One of the key aspects of this program is the training the students receive prior to the experience. One full session was dedicated to this training, where particular emphasis was placed on the fact that everyone stood to gain from the program and highlighting the benefits for both tutors and tutees. Its ultimate success largely depends on the students' attitude and interest; it is therefore essential that they have a positive perception of the program from the beginning. The students were informed of the program's aims and were invited to indicate which qualities they thought good tutors and tutees should have, which the teacher wrote on the blackboard. The most important qualities identified for tutors were 
showing respect and interest, and being understanding, patient and responsible; and for tutees, being hardworking and respectful, showing interest, and paying attention. They were also taught about the basis of peer tutoring, the basic rules, the tutor and tutee roles, and the benefits for both tutors and tutees.

-Materials and resources

The materials used in each session were the same worksheets the students worked with during the class. Each worksheet was handed out to the students and contained a theoretical question and a problem. The theoretical question was designed to be easy and to help the student solve the problem and strengthen their knowledge on this subject. The complexity of the problems varied according to the worksheet, and had either one or two sections. Extra activities were also added in case some pairs finished the task before the rest of the class.

Students were also given additional materials to help them understand the problem and tackle it with greater confidence. One example was the problem set in worksheet 6 . The students were asked to calculate the lateral area of a pyramid, a challenging task for pupils of that age due to the spatial vision it requires. Along with the worksheet the students were therefore given cardboard pyramids with a toothpick in the centre representing the height of the pyramid, and the apothem of the pyramid marked in pencil, the key data to calculate the lateral area.

Figure 1. Worksheet number 6 and the extra material provided for this session 
-Before and after the sessions. Classroom dynamic.

Prior to the sessions, the teacher prepared the list of tutors and their respective tutees. The students were told how much time they had to solve each question on the worksheets, which were completed entirely in class. The worksheets were handed out and the students worked on them without help. They only took them home to finish in exceptional circumstances if they could not complete them in class. When the time was over, if most of the tutors had solved the questions they gathered with the teacher for a few minutes while the tutees continued working on the worksheets, since the tutees were generally slower than the tutors. At this point the teacher checked the tutors' results and the methods they had followed to make sure they were appropriate. Before looking at the tutors' worksheets, the teacher had had time to walk around the desks, observe the results and help both tutors and tutees with any questions. During the session with the tutors, the teacher explained what they should have done to solve the problem. Once the teacher had checked that the tutors had the right answers and understood the problem, they started working with their respective tutees and the peer tutoring session began.

-Monitoring and assessment

Tutor and tutee worked autonomously during the tutoring process, while the teacher observed to ensure that the students were working properly. Assessing the results of peer tutoring is an important aspect of this process. The questionnaires that the students took before and after the program show whether the peer tutoring experience had positive effects on their learning, their perceptions of mathematics, or their social abilities. At the same time, students' attitudes in class and toward mathematics can also be observed on a day-to-day level. 


\section{Research design}

Quasi-experimental statistical design without control group was used due to the human ecologic nature of the study. Innovative education interventions in schools give rise to ethical problems concerning the use of control groups. In this particular study, we were unable to have a control group because no other group was working with the same subject contents at the same time, the lessons studied between the groups were mismatched, and they were assessed in different ways. Moreover, the second generation of studies on cooperative learning states that once the effect of this methodology has been demonstrated in relation to others (with comparative studies between groups), the focus should turn to the data from the process that may help to explain it. [43] The constructs covered in this study are mathematics self-concept, attitude of solidarity and academic performance. In order to review the mathematics self-concept and the attitude of solidarity students took the two questionnaires before and after the peer tutoring program (see quantitative instruments). The students' academic performance was compared using the marks from the first and second terms (before the program) and the marks from the third term (after the program).

\section{Participants}

The participants in the study were students from an eighth-grade class in Castellon de la Plana (Spain). Although 27 students were enrolled in the course, some of them were frequently absent from school, and only 18 students participated actively in the program, of whom 13 were girls and 5, boys. They were aged between 13 and 15 years, and 9 were Spanish, 7 Romanian, one Peruvian and one Chinese. This study employed a non-probability 
and random sampling method, as the choice of the sample did not depend on the probability, but on the possibility of access. [44]

\section{Techniques and instruments used to collect information}

\section{Quantitative instruments}

- $\quad$ The questionnaire designed and validated by Gil, Guerrero and Blanco [45] was used to measure students' mathematics self-concept (Questionnaire on beliefs and attitudes toward mathematics). The questionnaire has 52 items each with four possible answers (strongly disagree, disagree, agree and strongly agree). This questionnaire was selected for the research because it had already been used in other studies and because its authors took into account previous research on beliefs and attitudes of secondary school students toward mathematics.

- To measure the students' attitudes toward solidarity, we used the attitude of solidarity questionnaire designed and validated by Ortega and Minguez [46]. As in the previous case, this questionnaire was selected because it had already been used in previous studies on cooperative learning and peer tutoring. [47] The questionnaire's 23 items are evaluated on a 5-point Likert scale from very strongly disagree (1) to very strongly agree (5).

- $\quad$ The students' academic performance was measured by comparing their marks (out of 10) in the subject in the first and second term with those for the third term. During the first and second term, the teacher used traditional teaching methods in the class, whereas during the third term the peer tutoring program was implemented (10 sessions) alongside the teacher's lessons. 


\section{Qualitative instruments}

- The students' perceptions of peer tutoring were uncovered through discussion groups. This method consists of setting up an interview with a group of people chosen for their relevance to the research question. [48] The interview is unstructured and the composition of the group is usually heterogeneous. In our case, 14 questions were asked, of which 10 were addressed to the entire group, 2 were specifically addressed to the tutors and the other 2 specifically to the tutees.

- Participant observation was used to study the interactions and help given between peers to solve the problems. This type of observation has a high degree of researcher involvement in the situation being observed. Information is generally recorded as narrative, in which natural language is maintained to register everything observed without translating it into specific codes generated for research. [48] In this case the most relevant behaviours were written down in a field diary. The researchers observed the class, the tutor-tutee interaction and the classroom atmosphere.

\section{Data analysis}

SPPS software (version 22) was used to analyse the data collected from the questionnaires. This is a statistical program developed to analyse quantitative date. We obtained the statistical average and the standard deviation, and Student's t-test (95\% confidence level) was used to determine whether there were any significant differences between before and after the program. To ensure reliability of the mathematics self-concept 
and the attitude of solidarity questionnaires, Cronbach's alpha, Cronbach's alpha if item deleted and Guttman split-half for each questionnaire were run on the scores before the intervention. $[49,50]$ The information collected from the discussion groups was compared with that from the field diary to analyse the qualitative data. A descriptive analysis was carried out on the students' contributions in the discussion groups and the data gathered through participant observation. In order to guarantee the anonymity of the students and to identify their interventions, in the results section the interventions of the participants were coded in the following way: Discussion group (DG) / $\mathrm{T}$ (tutor), $\mathrm{t}$ (tutee) / number assigned to the participant.

\section{Results}

Quantitative results

We now present the results the students obtained before and after taking part in the peer tutoring program in the constructs of mathematics self-concept, attitude of solidarity, and academic performance.

\section{Academic performance}

In the case of academic performance, statistically significant differences were found between scores before and after the intervention. 18 students (n) took the first, second and third term exams. 9 of them were tutors and the other 9 were tutees. The mean grade for the first and second term was 4.25 out of 10 (before) with a standard deviation (SD) of 2.38, while the mean for the third term (after) was 6.01 out of 10 with a SD of 2.68. The statistical comparison (Student's t-test, 95\% confidence level) proved that there was a significant increase in the students' grades after the peer tutoring program $(.00, \mathrm{p}<.05)$. The 
students' marks improved on those for the first two terms in most cases. Only 2 students out of the 18 who took the third term exam obtained poorer marks than in the two previous terms. The percentage of students failing was considerably reduced and many students saw a significant increase in their marks.

Figure 2. Students' academic performance marks

Table 1. Students' grades before and after the peer tutoring program.

Statistically significant differences were also found when analysing tutors $(.03, \mathrm{p}<.05)$ and tutees $(.02, \mathrm{p}<0.05)$ separately. The mean grade for tutors for the first and second term was 6.01 out of 10 (before) with a standard deviation (SD) of 2.07 , while the mean for the third term (after) was 7.54 out of 10 with a SD of 2.46 . The mean grade for tutees for the first and second term was 2.49 out of 10 (before) with a standard deviation (SD) of 0.87 , while the mean for the third term (after) was 4.48 out of 10 with a SD of 1.96 .

Table 2. Tutors' grades before and after the peer tutoring program

Table 3. Tutees' grades before and after the peer tutoring program 


\section{Mathematics self-concept}

Nineteen students completed the mathematics self-concept questionnaire before and after the peer tutoring program. 9 of them were tutors, 9 were tutees and the remaining student changed his role depending on the day. Differences between scores before and after the intervention for this questionnaire were statistically significant $(.01, \mathrm{p}<.05)$ for a confidence level of $95 \%$ of Student's t-test. The mean score before the program was 2.72 out of 5 with a standard deviation (SD) of 0.24 , while the mean score after the program was 2.89 out of 5 with a SD of 0.23 .

Table 4. Mathematics self-concept questionnaire scores

When analysing tutors and tutees separately, statistically significant differences were found for tutors $(.04, \mathrm{p}<.05)$ but not for tutees $(.1, \mathrm{p}<.05)$. The mean score before the program for tutors was 2.85 out of 5 with a standard deviation (SD) of 0.21 , while the mean score after the program was 2.97 out of 5 with a SD of 0.22 . The mean score before the program for tutees was 2.59 out of 5 with a standard deviation (SD) of 0.23 , while the mean score after the program was 2.79 out of 5 with a SD of 0.22 .

Table 5. Tutors' self-concept scores before and after the peer tutoring program 
Table 6. Tutees' self-concept scores before and after the peer tutoring program

Reliability tests for this questionnaire showed a Cronbach's alpha of 0.704 and a Guttman split-half coefficient of 0.688 . Cronbach's alpha if item deleted ranged from $\alpha=$ 0.723 to $\alpha=0.677$.

Since a discussion of all the 52 items in the questionnaire would be very lengthy, we only review the items we consider to be of special relevance. First are the items related to the students' view of mathematics, which should have improved after the peer tutoring program. That is the case of items 1 (mathematics is useful and necessary in all areas of life), 2 (mathematics are difficult, boring and have little to do with reality), and 9 (the abilities and skills that I develop in class to solve problems have nothing to do with the ones I use to solve problems in my daily life). Figure 3 shows the average scores for these items before and after the peer tutoring program.

Figure 3. Mean scores (before and after the program) for items 1,2 and 9 of the mathematics self-concept questionnaire.

Second are the items related to students' confidence in their abilities when solving mathematical problems: items 17 (when I solve a problem I am not usually sure if the result is correct), 18 (I have confidence in myself when I take on mathematical problems), 19 (I 
consider myself very capable and competent at mathematics), 44 (I usually quit when I come up against a difficult mathematical problem), 45 (when I work on a mathematical problem I am very curious to know the answer), and 46 (I feel anxious and fearful when the teacher asks me by surprise to solve a problem). Improvements were seen in all these items, as shown in figure 4.

Figure 4. Mean scores (before and after the program) for items 17, 18, 19, 44, 45 and 46 of the mathematics self-concept questionnaire.

Attitude of solidarity

Nineteen students (n) took the attitude of solidarity questionnaire before and after the peer tutoring program. The mean score before the intervention for this questionnaire was 3.35 out of 5 with a standard deviation (SD) of 0.37 , while the mean score after the intervention was 3.62 out of 5 with a SD of 0.39 . Differences between scores before and after the intervention for this questionnaire were statistically significant $(.00, \mathrm{p}<.05)$ for a confidence level of $95 \%$ of the Student's t-test.

Table 7. Attitude of solidarity questionnaire scores (before and after the program)

\footnotetext{
When analysing tutors and tutees separately, statistically significant differences were found for both tutors $(0.01, \mathrm{p}<.05)$ and tutees $(0.04, \mathrm{p}<.05)$. The mean score before the program for tutors was 3.35 out of 5 with a standard deviation (SD) of 0.36 , while the mean 
score after the program was 3.60 out of 5 with a SD of 0.31 . The mean score before the program for tutees was 3.39 out of 5 with a standard deviation (SD) of 0.39 , while the mean score after the program was 3.67 out of 5 with a SD of 0.50 .

Table 8 . Tutors' solidarity scores before and after the peer tutoring program

Table 9. Tutees' solidarity scores before and after the peer tutoring program

Reliability tests for this questionnaire showed a Cronbach's alpha of 0.736 and a Guttman split-half coefficient of 0.704. Cronbach's alpha if item deleted ranged from $\alpha=$ 0.751 to $\alpha=0.692$.

Items in which we detected the greatest improvements in students' scores were items 10 (It is not worth complicating things to help others), item 13 (collaborating with others is a waste of time and a useless task), 14 (given the few resources that I have, I can't do much to help others) and 15 (my studies can only benefit me, not others)

The results of this study therefore allow us to confirm the first three research hypotheses. 


\section{Qualitative results}

The teachers noted that most of the students positively engaged with this methodology and felt comfortable in a situation in which some of the tutees expressed a desire to become tutors. "We have enjoyed a lot working in pairs, but I would have liked to be a tutor and explain things to my peer that he doesn't know" (DG, t2). None of the tutors wanted to give up their role as tutor and went to great lengths to keep it. This observation was confirmed in the discussion groups where most of the students claimed that they had found the methodology useful in helping them to solve the mathematical problems "I always had the worksheet done and prepared because the teacher reviewed it and if it was done we knew that we would continue being tutors (DG, T4). They stated that the worksheets had enabled them to review what they had learned in class, and they were helpful in preparing for the exam.

Furthermore, because the students were taking an active role in their work in class, they accepted it as normal when the teacher asked one student to explain to a classmate an exercise they had successfully solved. In this way, the teacher could help more students at the same time in the class. As the sessions advanced, more peer tutoring situations took place during the daily teaching period and outside the peer tutoring program, "Sometimes, even if it's not mathematics class, I also ask my tutor to help me when I don't understand something". (DG, t8). Most of the tutors stated that they found it very useful to help their peers with the problems. Some tutors also valued the program as a different and unconventional alternative to what they normally do in class, "In the other subjects we always do the same, the teacher explains and then we do the exercises, but here we are the teachers and we can help our peers" (DG, T6). For their part, almost all the tutees 
considered the methodology had been useful, and especially praised their peers' excellent explanations and teaching, "When my tutor explained to me I understood it better, I understood her words, they were much easier for me"' (DG, t1).

Regarding the students' attitude, from day one a healthy competition was noted, started by some of the tutees who aspired to become tutors. They made greater efforts in class and they did their best to become tutors at some point in the future. This attitude was manifest by some tutees calling attention to the teacher and showing their correct answers while the teacher was talking with the tutors, "I would have liked to be a tutor. Sometimes I showed the worksheet to the teacher so he could see I was working hard" (DG, t3). These tutees' insistence earned them the title of 'all-rounder tutors'. All-rounder tutors are tutees who are waiting for their chance to become a tutor and if one of the tutors does not attend class, they take on that role. In addition most of the tutors were observed to make a great effort. None of them wanted to lose their position and they made every effort to solve the problems to the best of their ability. This attitude was confirmed in the discussion groups. When they were asked how they felt in their respective positions, most of them answered that they had felt important, "I think I have helped my tutored peer a lot. Besides, as I explained it looked like I was the teacher" (DG, T4). Furthermore, although the tutees gave diverse responses when asked about their position, none of them reported feeling uncomfortable or annoyed.

In this regard, a considerable improvement was noted in the students' social skills. We also observed that most of them had lost the shyness they had before the peer tutoring program. At the beginning of the program, the students had to be asked to go to the board. After a few sessions, both tutors and tutees insisted on going to the board by themselves and, despite knowing that they would have to explain the problem to all their peers, they were not afraid or embarrassed to do so. Even those who were more competent at 
mathematics had been nervous about explaining a problem before the program started. During the discussion groups, most of the students said they found it easier to explain a problem on the board than before the peer tutoring program, "Now going up to the blackboard and explaining problems is easier for me. I think I have already practised with my peer and I'm not afraid"' (DG, T7).

A considerable improvement was also observed in the classroom dynamics as the sessions progressed. The students finished the worksheets more quickly than before and had a better understanding of the steps of the process. The improvement on the first sessions was considerable. What the students most liked about the worksheets was that the problems they worked with were quite different from the ones they worked with in class. Some students stated that the best thing about the program was that they had learned more and that it had been easier for them to take the exam, "As the worksheets contained exercises similar to the ones in the exam, I remember how they explained to me and I was able to do them". This is consistent with the question "Would you like to try another cooperative learning technique?" which all students answered in the affirmative. All the students stated that they would be pleased to work in groups, although some of them pointed out that every single member of the group must make a commitment to carry out the tasks assigned to them.

\section{Discussion of results}

As stated previously, the results from the quantitative information revealed statistically significant differences in the three constructs tested (academic performance, mathematics self-concept and attitude of solidarity) after the experience. The first three research 
hypotheses are therefore confirmed. In the same vein, we found studies conducted by Karsenty [51] and Gautreaux [52], who showed that their peer tutoring programs in mathematics and secondary education increased their students' academic performance. Similar results were found in studies by Schneck [53], Lazarus [54] and Calhoon and Fuchs [55] in which the effects of peer tutoring programs on students' academic performance were tested with pretest-posttest control group designs. All these studies found significant increases between the mean score before the peer tutoring program and the mean score after the peer tutoring program. This improvement is in line with the meta-analysis conducted by Leung [15], which showed that peer tutoring has a positive impact on students' academic achievement and that same-age tutoring can have a considerable positive effect on the students.

Regarding the students' mathematics self-concept, two previous peer tutoring experiences by Fantuzzo and Davis, and Topping et al. in mathematics showed increases in this construct $[56,57]$. Although these studies were conducted in primary education and one of them involved cross-age tutoring, they support the mathematics self-concept results found in this study. Another peer tutoring study conducted by Mosca and Santiviago [58] for new students enrolling in college mathematics courses found improved perceptions of students' own skills. It is important to note that while all these studies used a qualitative approach to analyse mathematics self-concept, in this research we followed a quantitative approach. Although not in the field of mathematics, we found successful peer tutoring experiences also including self-concept conducted by Topping, Duran and Van Keer, H. [59] and Flores and Duran [60] in reading skills, and by Alrajhi and Aldhafri [61] in learning English, which also showed that peer tutoring had positive effects on students' self-concept. The fact that tutees' self-concept improvement was not significant is 
supported by Flores and Duran [60]. As they state [60, p. 309] "tutees are likely to attribute such improvement to the help received from their tutors instead of acknowledging their own dedication and efforts".

Regarding attitude of solidarity, previous studies conducted by Maheady [62] and Robinson and Steers-Wentzell [63] indicated that peer tutoring may lead to significant improvements in the attitudes of mathematics students. Theoretical research on cooperative learning also reports that attitudes of solidarity usually increase after this type of experience $[64,65]$. Studies in fields other than mathematics but also involving peer tutoring and attitude of solidarity include those by Miravet, Ciges and Garcia [66] in the college subject of general didactics, and Miravet, Garcia and Ciges in biology [67], which also reported an increase in students' attitudes of solidarity.

These increases detected in all the analysed constructs coincide with the findings of the meta-analysis conducted by Cohen, Kulik and Kulik [68] which stated that "tutoring benefits both tutors and tutees on both the cognitive and affective levels".

With regard to the qualitative information, first we analyzed the degree of satisfaction expressed by the students with the peer tutoring program through the discussion group. It was noted that most of the students were satisfied with this method and they valued it positively. Most of them also said they would be interested in trying other cooperative learning techniques, confirming that they were motivated and interested in this particular technique and in methods that require students to participate actively. This may be due to the friendly environment this type of method generates among the students, and to the 
tutors' use of language and examples that are most appropriate for the age of the tutees. [69, 70] In addition, the more relaxed environment and individual attention enabled them to ask questions without fear and to receive an immediate answer. [13] This is illustrated by the way all the students were actively involved in solving the problems: the tutors went to great pains to explain all the exercises to their tutees, and the tutees paid great attention to their tutors' explanations. Maheady [62] and Topping et al. [71] also reported high levels of satisfaction with the methodology among the students in their studies.

The students' perceptions of the program were also investigated. Most of them described it as useful and different to the way they were used to working. We found diverse opinions regarding the tutees' feelings about their position in the program, although none of them said they felt uncomfortable or annoyed. All the tutors said that they felt important in their positions, a feeling that has been observed in other peer tutoring programs with other subjects, such as Schleyer et al. [72] or Gillies [73]. The tutors in their studies expressed a feeling of responsibility and importance in their roles during the program. This feeling is directly related to the tutors' high efforts. None of the tutors wanted to lose their position and strived to do the exercises to the best of their abilities. This may be due to the fact that they felt responsible for their peers' learning, they had made a commitment, and they were given certain "power". Perhaps because all the tutors had to meet together before working with their tutees, and because everyone would know who had performed their role well and who had not, peer pressure may have motivated them all to do their best and show the others that they knew what they were doing.

Finally, we contrast the quantitative information (mathematics self-concept, academic performance and attitude of solidarity) with the information collected through the discussion groups and the participant observation. The significant improvement detected in 
the test on the mathematics self-concept analysis was contrasted not only with the interviews with the students, but also with the daily attitude observed toward the subject. All the students stated that mathematics was a useful subject and most of them said that they thought it was necessary for almost everything in our lives. Furthermore, they claimed to feel more confident when tackling the problems and relied more on their own skills to solve and explain them to their peers than before the peer tutoring program. The daily attitude observed also chimes with this increase detected in the mathematics self-concept, as almost all the students wanted to go to the board and solve the problems in class despite knowing they would have to explain them later to their classmates, reflecting their high levels of self-confidence. Moreover, the increase detected quantitatively in the academic performance was also reflected in field diary observations that some of the students who had previously been more reluctant to work in class were now making great efforts and seemed truly interested in the subject. Similarly, the increase in the attitude of solidarity detected in the tests was also seen in the participant observation, where it was noted that several times students explained exercises to others when a classmate asked for help or without being asked. All these observations, together with the self-concept, confirms hypothesis 4 not only because a considerable improvement was detected in the students' communicative abilities, but also because they felt competent to explain to their classmates the exercises they had previously solved. These improvements have also been detected in other studies such as Tsuei [74] and Topping et al. [75].

\section{Conclusions}


This research appears to show that peer tutoring has a high influence on emotional, attitudinal and academic factors and on students' communicative abilities, as well as having positive effects in the classroom. The results have shown how the students themselves can become a powerful teaching-learning resource for their classmates. In addition, this methodology affords the teacher the opportunity to exploit this potential by turning the interactions between the students into learning situations.

Peer tutoring is therefore a dynamic, enjoyable methodology that encourages participation and offers an alternative way to learn. It also raises students' awareness of the importance and utility of helping between classmates, both for other students and for themselves.

The results in this research are promising, although the study has certain limitations that must be taken into account. The first of these concerns the number of sessions. The students participated in only 10 peer tutoring sessions. On one hand, the fact that only a few sessions produced such significant outcomes is a good sign that the methodology can be effective even in short-term programs. Nevertheless, a longer period of analysis, together with more sessions and more than one test may have yielded a more reliable analysis of this methodology. In addition, we had no control group, which would have allowed a broader and more reliable analysis of the quantitative constructs. However, given its aforementioned potential, we consider peer tutoring to be an appropriate cooperative learning method for working with mathematics. In addition, the results should be interpreted with caution. The fact that this program was held during the third term - a period students always regard as crucial and stimulates them to work harder due to the proximity of the end of course exams - may have produced results that would not have been achieved had the program been run in the second or first term. Moreover, the scores 
before the program showed this was already an academically competent, confident and supportive group of students before the peer tutoring program. Hence their positive attitudes and cognitive competence facilitated the development of the program.

Furthermore, the mere fact that the teaching method was entirely different in the third term could also have contributed raising the students' academic performance, regardless of the type of learning methodology implemented. The fact that students took the mathematics self-concept questionnaire for the second time (after the intervention) after the third term exam may also have influenced the scores of this test. After taking the third term exam the students may already have known their marks would be better than previous terms, which may have led to higher answers on the mathematics self-concept questionnaire. The lower academic performance of two students must also be taken into account, especially considering they had achieved passing grades in the previous terms. Their attitude during the program was poor compared to their classmates and they did not express a great deal of confidence in this methodology. This shows that although peer tutoring may be beneficial for the students, it can have no effect if they do not perceive it as useful and trust it as a beneficial way of learning.

Reliability tests (Cronbach's alpha, Guttman and Spearman Brown coefficients) for the mathematics self-concept and the attitude of solidarity questionnaires showed values that may be considered acceptable, but not excellent. Caution is needed when interpreting the reliability analysis, especially taking into account the elevated number of items in the two questionnaires (52 and 23 items each). [76] The fact that the sample was small (only 19 students) must also be considered. [77, 78] Future research using these questionnaires should run reliability tests. 
This research is a further illustration of how to teach in diversity and inclusive education in secondary school classrooms.

\section{References}

[1] Ainscow M, Miles S. Making Education for All inclusive: where next?. Prospects. 2008;38(1), 15-34.

[2] Sheehy K. Ethics and research in inclusive education: values into practice. Psychology Press; 2005.

[3] Fernández-Batanero, JM. ¿Educación inclusiva en nuestros centros educativos? Sí, pero ¿cómo?. Contextos educativos: Revista de educación. 2005;8: 135-148.

[4] Ashman A, Gillies R. Cooperative learning: The social and intellectual outcomes of learning in groups. Routledge; 2003.

[5] Coll C. Estructura grupal, interacción entre alumnos y aprendizaje escolar. Infancia y aprendizaje. 1984;7(27-28),119-138.

[6] Vygotsky L. Interaction between learning and development. Readings on the development of children. 1978; 23(3), 34-41.

[7] Duran D. Tutoría entre iguales. Innovación Educativa. 2004; 75: 63-68.

[8] Topping K. The efectiveness of peer tutoring in further and higher education: A typology and review of the literature. Higher Education. 1996;32(3):321-345.

[9] Linton R. The effects of grade displacement between students tutors and students tutored. Dissertation Abstracts International. 1973; 33:8-a, 4091.

[10] Lippit, P. Learning through cross-age helping: Why and how. Children as teachers, theory and research on tutoring. 1976; 157-168.

[11] Allen V, Feldman R. Studies on the role of tutor. Children as teachers: Theory and research on tutoring. 1976; 113-129.

[12] Burnish P. Peer-assisted learning strategies: An evidence-based practice to promote reading achievement. Learning Disabilities Research \& Practice. 2005; 15(2): 85-91.

[13] Topping, K. Peer-assisted learning: A practical guide for teachers. Newton, Massachusetts: Brookline Books; 2008. 
[14] Duran, D. Una experiencia de tutoría entre iguales, método de aprendizaje cooperativo para la diversidad. Congreso Internacional Una escola per a tothom: Barcelona; 2003

[15] Leung, K. Preliminary empirical model of crucial determinants of best practice for peer tutoring on academic achievement. Journal of Educational Psychology. 2015; 107(2), 558.

[16] Ritter G, Denny G, Albin G, Barnett J, Blankenship V. The effectiveness of volunteer tutoring programs: A systematic review. Campbell Systematic Reviews; 2006:7.

[17] Spencer, VG. Peer tutoring and students with emotional or behavioral disorders: A review of the literature. Behavioral Disorders. 2006: 204-222.

[18] Byrd, DE. Peer tutoring with the learning disabled: A critical review. The Journal of Educational Research. 1990; 84(2):115-118.

[19] Flores M, Duran D. Effects of peer tutoring on reading self-concept. International Journal of Educational Psychology. 2013; 2(3):297-324.

[20] Gavota, MC, Cattaneo A, Arn C, Boldrini E, Motta E, Schneider D, Betrancourt M. Computer-supported peer commenting: a promising instructional method to promote skill development in vocational education. Journal of Vocational Education and Training. 2010; 62(4): 495-511.

[21] Scheeler MC, Macluckie M, Albright K. Effects of immediate feedback delivered by peer tutors on the oral presentation skills of adolescents with learning disabilities. Remedial and special education. 2010; 31(2): 77-86.

[22] Spörer N, Brunstein JC, Kieschke, ULF. Improving students' reading comprehension skills: Effects of strategy instruction and reciprocal teaching. Learning and Instruction. 2009;19(3):272-286.

[23] Duran D, Monereo C. The impact of peer tutoring on the improvement of linguistic competence, self-concept as a writer and pedagogical satisfaction. School Psychology International. 2008;29(4):481-499.

[24] Ismail HN, Alexander JM. Learning within scripted and nonscripted peer tutoring sessions: The Malaysian context. The Journal of Educational Research. 2005; 99(2):67-77.

[25] Gautreaux, G. The effects of monitoring training on the acquisition of an observational learning repertoire under peer tutoring conditions, generalization and collateral effects (Doctoral dissertation, [S1: sn]); 2005. 
[26] Nazzal, A. Peer tutoring and at-risk students: An exploratory study. Action in teacher Education. 2002;24(1):68-80.

[27] Knowles, A. International Encyclopedia of Higher Education. Jossey-Bass; 1977.

[28] Martin A, Debus R. Self-reports of mathematics self-concept and educational outcomes: The roles of ego-dimensions and self-consciousness. British Journal of Educational Psychology. 1998; 68(4):517-535.

[29] Pajares, F. Motivational role of self-efficacy beliefs in self-regulated learning. Motivation and self-regulated learning: Theory, research, and applications. 2008: 111-139.

[30] Miñano P, Castejón J. Variables cognitivas y motivacionales en el rendimiento académico en Lengua y Matemáticas: un modelo estructural. Revista Psicodidáctica. 2011; 16(2):203-230.

[31] Pintrich P, Marx R, Boyle R. Beyond cold conceptual change: The role of motivational beliefs and classroom contextual factors in the process of conceptual change. Review of Educational research. 1993; 63(2): 167-199.

[32] Hattie, J. Self-concept. Psychology Press; 2014.

[33] Shavelson R, Bolus R. Self-concept: the interplay of theory and methods. Journal of Education Psychology. 1982; 74(1):3-17.

[34] Gómez-Chacón, I. Matemática emocional. Los afectos en el aprendizaje matemático. Madrid: Narcea. 2000.

[35] Young-Loveridge, J. Two Decades of Mathematics Education Reform in New Zealand: What Impact on the Attitudes of Teacher Education Students? Annual Meeting of the Mathematics Education Research Group of Australasia. Freemantle: Western Australia. 2010.

[36] Ifamuyiwa, S. A., \& Akinsola, M. K.. Improving senior secondary school students' attitude towards mathematics through self and cooperative-instructional strategies. International journal of mathematical education in science and technology. 2008;39(5):569-585.

[37] Hondrich K, Koch-Arzberger C. Solidarität in der modernen Gesellschaft. Fischer Taschenbuch-Verlag; 1992.

[38] Cortina, A. Ciudadanos Del Mundo: Hacia Una Teoría De La Ciudadanía. Madrid: Alianza Editorial; 1998.

[39] Robbins, S. Organizational behavior: Concepts, controversies, and applications. Prentice Hall; 1991. 
[40] Hollander E. Principles and methods of social psychology. New York: Oxford University Press; 1967.

[41] Roche Olivar, R. Psicología y educación para la prosocialidad. Ciudad Nueva. Buenos Aires; 1998.

[42] Escámez, J. Solidaridad y voluntariado social. Valencia: Fundació Bancaixa; 1999.

[43] Moliner, L., Flores, M., \& Duran, D. (2011). Efectos sobre la mejora de las competencias lingüísticas y la autoimagen lectora a través de un programa de tutoría entre iguales. Revista de Investigación en Educación. 2011;9(2):209-222.

[44] Albert, M. La investigación educativa. Claves teóricas. Madrid: McGraw Hill. 2006.

[45] Gil N, Guerrero E, Blanco L. El dominio afectivo en el aprendizaje de las matemáticas. Revista Electrónica de Investigación Psicoeducativa. 2006; 8(4):4772.

[46] Ortega P, Mínguez, R. Educación moral: una propuesta alternativa. Revista de Ciencias de la Educación. 1992; 149:69-77.

[47] Moliner L, Moliner O, Sales A. Enseñar y aprender Biología y Geología a través de la tutoría entre iguales. Enseñanza de las ciencias. 2013; 31(3);189-206.

[48] León O, Montero I. Métodos de investigación en psicología y educación. Madrid. McGraw Hill; 2004.

[49] Cronbach, L. Coefficient alpha and the internal structure of tests. Psychometrika. $1951 ; 16(3): 297-334$.

[50] Novick, M. R., \& Lewis, C. Coefficient alpha and the reliability of composite measurements. Psychometrika. 1967; 32(1):1-13.

[51] Karsenty, R. Nonprofessional mathematics tutoring for low-achieving students in secondary schools: A case study. Educational Studies in Mathematics. 2010:74(1);1-21.

[52] Gautreaux, G. The effects of monitoring training on the acquisition of an observational learning repertoire under peer tutoring conditions, generalization and collateral effects. Teachers College: Columbia University; 2005.

[53] Schneck, A. J. The Effects of After-School Peer Tutoring Programs in Mathematics. Doctoral dissertation, University of Minnesota; 2010. 
[54] Lazarus K. Effect of peer tutoring and cooperative learning instructional strategies on mathematics achievement of students with learning disabilities in Oyo State, Nigeria. African Journal for the psychological studies of social issues. 2014; 17(1):96-105.

[55] Calhoon M, Fuchs L. The effects of peer-assisted learning strategies and curriculum-based measurement on the mathematics performance of secondary students with disabilities. Remedial and Special Education. 2003; 24(4):235-245.

[56] Fantuzzo J, Davis G, Ginsburg M. Effects of parent involvement in isolation or in combination with peer tutoring on student self-concept and mathematics achievement. Journal of Educational Psychology. 1995; 87(2):272.

[57] Topping K, Campbell J, Douglas W, Smith A. Cross-age peer tutoring in mathematics with seven-and 11-year-olds: Influence on mathematical vocabulary, strategic dialogue and self-concept. Educational Research. 2003:45(3), 287-308.

[58] Mosca A, Santiviago C. Fundamentos conceptuales de las tutorías entre pares. La experiencia de la Universidad de la República. Programa de respaldo al aprendizaje. UDELAR; 2012.

[59] Topping, K., Duran, D., \& Van Keer, H. Using Peer Tutoring to Improve Reading Skills: A Practical Guide for Teachers. Routledge; 2004.

[60] Flores, M., \& Duran, D. (2013). Effects of peer tutoring on reading self-concept. International Journal of Educational Psychology, 2(3), 297-324.

[61] Alrajhi, M. N., \& Aldhafri, S. S. (2015). Peer Tutoring Effects on Omani Students' English Self-Concept. International Education Studies, 8(6), 184.

[62] Maheady L. Classwide Peer Tutoring: Practice, Theory, Research, and Personal Narrative. Intervention in School and Clinic. 2010; 46(2):71-78.

[63] Robinson D, Steers-Wentzell K. Peer and Cross-Age Tutoring in Math: Outcomes and Their Design Implications. Educational Psychology Review. 2005; 17(4):327362.

[64] Pajares F, Urdan T. Educating adolescents: Challenges and strategies. IAP; 2004.

[65] Gillies, R. Enhancing Classroom-Based Talk. Routledge; 2016.

[66] Miravet LM, Ciges, AS, García OM. An experience of reciprocal peer tutoring at the university. Procedia-Social and Behavioral Sciences. 2014; 116:2809-2812.

[67] Miravet LM, García OM, Ciges AS. Enseñar y aprender Biología y Geología a través de la tutoría entre iguales. Enseñanza de las ciencias: revista de investigación y experiencias didácticas, 31(3), 189-206; 2013. 
[68] Cohen P, Kulik J, Kulik, C.L. Educational outcomes of tutoring: a meta-analysis of findings. American Educational Research Journal, 1982; 19(2):237-48.

[69] Sinha, T., Zhao, R., \& Cassell, J. Exploring socio-cognitive effects of conversational strategy congruence in peer tutoring. In Proceedings of the $1^{\text {st }}$ Workshop on Modeling Interpersonal Synchrony and influence. 2015:11; 5-12.

[70] DuPaul G, Ervin R, Hook C, et al. Peer tutoring for children with attention deficit hyperactivity disorder: Effects on classroom behavior and academic performance. Journal of applied behavior analysis. 1998:31(4); 579-592.

[71] Topping K, Kearney M, McGee E, et al. Tutoring in mathematics: a generic method. Mentoring and Tutoring. 2004:12(3); 353-370.

[72] Schleyer G, Langdon G, James S. Peer tutoring in conceptual design. European Journal of Engineering Education. 2005:30(2); 245-254.

[73] Gillies, A. The cross-age tutoring experience for students with and without disabilities. International Research in Early Childhood Education. 2013:4(1); 105126.

[74] Tsuei, M. Using Synchronous Peer Tutoring System to Promote Elementary Students' Learning in Mathematics. Computers \& Education. 2012:58(4); 11711182.

[75] Topping K., Miller D, Murray P, et al. Outcomes in a Randomised Controlled Trial of Mathematics Tutoring. Educational Research. 2011; 53(1):51-63.

[76] Cortina, J. M. (1993). What is coefficient alpha? An examination of theory and applications. Journal of applied psychology, 78(1), 98.

[77] Nunnally JC, Bernstein IH. Psychometric theory. 3. New York: McGraw-Hill; 1994.

[78] Raykov T, Marcoulides GA. Introduction to psychometric theory. New York: Routledge; 2011 
Worksheet number 6

Unit 9-Geometric shapes

THE UJI PYRAMID

At the University of Castellon there is a square pyramid made of ceramics. It was built inside the teachers' department at the School of Technology and Experimental Sciences. The Dean wants to varnish the pyramid. A painter asks for $50 £$ per $\mathrm{m}^{2}$. Calculate how much it will cost if we know the following dimensions of the pyramid:

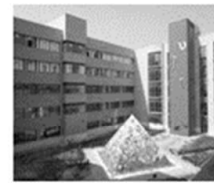

Dimensions of the pyramid:

IIeight of the pyramid: 5 meters

Side of the base: 4 meters

Figure 1. Worksheet number 6 and the extra material delivered for this session 


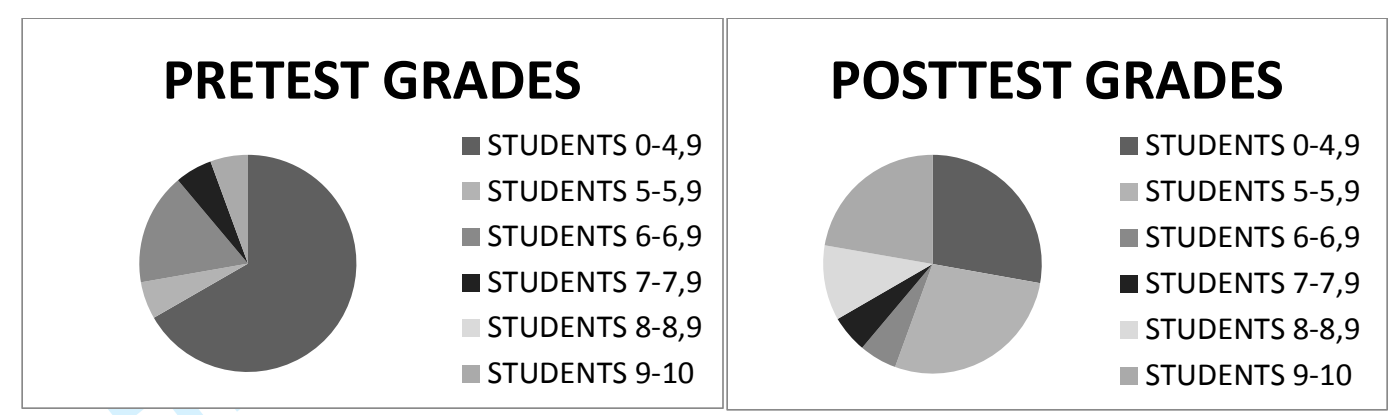

Figure 2. Students' marks before and after the peer tutoring program. 
Figure 3. Averages before and after intervention of items 1, 2 y 9 from the mathematical self-concept questionnaire. 


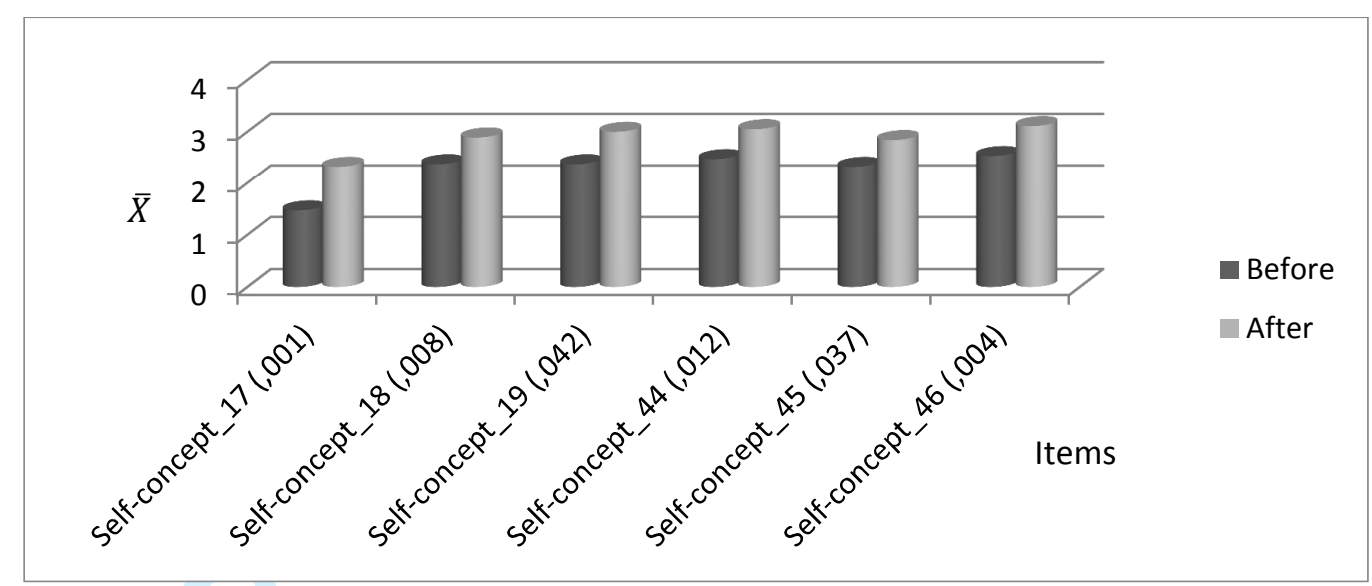

Figure 4. Averages before and after intervention of items 17, 18, 19, 44, 45 and 46 from the mathematical self-concept questionnaire. 


\begin{tabular}{|c|c|c|c|c|c|c|}
\hline \multirow{2}{*}{$\begin{array}{c}\text { Academic } \\
\text { Performance }\end{array}$} & \multicolumn{2}{|c|}{ Marks before intervention } & \multicolumn{3}{c|}{ Marks after intervention } \\
\cline { 2 - 7 } & Mean & SD & $\mathrm{n}$ & Mean & SD & $\mathrm{n}$ \\
\hline Significance level $(.00, \mathrm{p}<.05)$ & 4.25 & 2.38 & 18 & 6.01 & 2.68 & 18 \\
\hline
\end{tabular}

Table 1. Students' grades before and after the peer tutoring program. 


\begin{tabular}{|c|c|c|c|c|c|c|}
\hline Academic & \multicolumn{3}{|c|}{ Marks before intervention } & \multicolumn{3}{c|}{ Marks after intervention } \\
\cline { 2 - 7 } Performance (tutors) & Mean & SD & $\mathrm{n}$ & Mean & SD & $\mathrm{n}$ \\
\hline Significance level $(.03, \mathrm{p}<.05)$ & 6.01 & 2.07 & 9 & 7.54 & 2.46 & 9 \\
\hline
\end{tabular}

Table 2. Tutors' grades before and after the peer tutoring program 


\begin{tabular}{|c|c|c|c|c|c|c|}
\hline \multirow{2}{*}{$\begin{array}{c}\text { Academic } \\
\text { Performance (tutees) }\end{array}$} & \multicolumn{2}{|c|}{ Marks before intervention } & \multicolumn{3}{c|}{ Marks after intervention } \\
\cline { 2 - 7 } & Mean & SD & $\mathrm{n}$ & Mean & SD & $\mathrm{n}$ \\
\hline Significance level $(.02, \mathrm{p}<.05)$ & 2.49 & 0.87 & 9 & 4.48 & 1.96 & 9 \\
\hline
\end{tabular}

Table 3. Tutees' grades before and after the peer tutoring program 


\begin{tabular}{|c|c|c|c|c|c|c|}
\hline \multirow{2}{*}{$\begin{array}{c}\text { Mathematical } \\
\text { self-concept }\end{array}$} & \multicolumn{3}{|c|}{ before intervention scores } & \multicolumn{3}{|c|}{ after intervention scores } \\
\cline { 2 - 7 } & Mean & SD & $\mathrm{n}$ & Mean & SD & $\mathrm{n}$ \\
\hline Significance level $(.01, \mathrm{p}<.05)$ & 2.72 & 0.24 & 19 & 2.89 & 0.23 & 19 \\
\hline
\end{tabular}

Table 4. Mathematics self-concept questionnaire scores 


\begin{tabular}{|c|c|c|c|c|c|c|}
\hline \multirow{2}{*}{$\begin{array}{c}\text { Mathematical } \\
\text { self-concept (tutors) }\end{array}$} & \multicolumn{3}{|c|}{ before intervention scores } & \multicolumn{3}{c|}{ after intervention scores } \\
\cline { 2 - 7 } & Mean & SD & $\mathrm{n}$ & Mean & SD & $\mathrm{n}$ \\
\hline Significance level $(.04, \mathrm{p}<.05)$ & 2.85 & 0.21 & 9 & 2.97 & 0.22 & 9 \\
\hline
\end{tabular}

Table 5. Tutors' self-concept scores before and after the peer tutoring program 


\begin{tabular}{|c|c|c|c|c|c|c|}
\hline Mathematical & \multicolumn{3}{|c|}{ before intervention scores } & \multicolumn{3}{c|}{ after intervention scores } \\
\cline { 2 - 7 } self-concept (tutees) & Mean & SD & $\mathrm{n}$ & Mean & SD & $\mathrm{n}$ \\
\hline Significance level $(.09, \mathrm{p}<.1)$ & 2.59 & 0.23 & 9 & 2.79 & 0.22 & 9 \\
\hline
\end{tabular}

Table 6. Tutees' self-concept scores before and after the peer tutoring program 


\begin{tabular}{|c|c|c|c|c|c|c|}
\hline \multirow{2}{*}{$\begin{array}{c}\text { Solidarity } \\
\text { attitude }\end{array}$} & \multicolumn{2}{|c|}{ scores before intervention } & \multicolumn{3}{c|}{ Scores after intervention } \\
\cline { 2 - 7 } & Mean & SD & $\mathrm{n}$ & Mean & SD & $\mathrm{n}$ \\
\hline Significance level $(.00, \mathrm{p}<.05)$ & 3.35 & 0.37 & 19 & 3.62 & 0.39 & 19 \\
\hline
\end{tabular}

Table 7. Attitude of solidarity questionnaire scores (before and after the program) 


\begin{tabular}{|c|c|c|c|c|c|c|}
\hline Solidarity & \multicolumn{3}{|c|}{ Scores before intervention } & \multicolumn{3}{c|}{ Scores after intervention } \\
\cline { 2 - 7 } Attitude (tutors) & Mean & SD & $\mathrm{n}$ & Mean & SD & $\mathrm{n}$ \\
\hline Significance level $(.01, \mathrm{p}<.05)$ & 3.35 & 0.36 & 9 & 3.60 & 0.31 & 9 \\
\hline
\end{tabular}

Table 8 . Tutors' solidarity scores before and after the peer tutoring program 


\begin{tabular}{|c|c|c|c|c|c|c|}
\hline \multirow{2}{*}{$\begin{array}{c}\text { Solidarity } \\
\text { Attitude(tutees) }\end{array}$} & \multicolumn{2}{|c|}{ Scores before intervention } & \multicolumn{3}{c|}{ Scores after intervention } \\
\cline { 2 - 7 } & Mean & SD & $\mathrm{n}$ & Mean & SD & $\mathrm{n}$ \\
\hline Significance level $(.04, \mathrm{p}<.05)$ & 3.39 & 0.39 & 9 & 3.67 & 0.50 & 9 \\
\hline
\end{tabular}

Table 9. Tutees' solidarity scores before and after the peer tutoring program 